\title{
RETROCESSO NO DIREITO DE FAMÍLIA
}

\author{
Antonio Junqueira de Azevedo \\ Professor Titular do Departamento de Direito Civil da FDUSP \\ Ex-Diretor da Faculdade de Direito da Universidade de São Paulo
}

\begin{abstract}
Resumo:
O artigo critica o Livro do Direito de Família do Projeto de Código Civil, aprovado neste ano (1998), no Senado Federal; trata-se, porém, de Projeto de Código Civil elaborado há mais de vinte anos, na década de 70, antes da promulgação da Constituição da República, de 1988. Em virtude disso, já surge ultrapassado, sendo até mesmo inconstitucional em diversos de seus artigos.
\end{abstract}

Abstract:

The article criticizes the Family Law of the Civil Code Project, approved this year (1998), at the Federal Senate; it regards, though, of Civil Code Project elaborated twenty years back, on seventies, before the Republic Constitution promulgation, on 1988. Due that, it appears overshot, even unconstitutional in a number of its articles.

Unitermos: Direito de Família; Projeto de Código Civil; Constituição Federal.

Três são os tipos de família previstos na Constituição de 88: a família tradicional, constituída pelo casamento civil; a união estável, constituída pela união do homem e da mulher sem casamento civil; e a monoparental, constituída por um ascendente, homem ou mulher, e seus descendentes. Como até então se determinava que a família era constituída exclusivamente pelo casamento (Constituição anterior, art. 175), vê-se bem que houve uma mudança de 180 graus no espírito do Direito de Família: em essência, a família deixou de ser considerada somente como entidade jurídica, para ser concebida, antes de mais nada, como entidade natural. Infelizmente, o Projeto de Código Civil, tal e qual aprovado pelos senadores, não assimilou o espírito dos novos tempos.

Para começar, o Projeto não trouxe regra alguma sobre a família monoparental. No entanto, nada mais nada de menos do que $26,1 \%$ de brasileiros 
vivem nesse tipo de família. Em 1991, eram 38 milhões de pessoas, no total de 146 milhões (PNAD Pesquisa Nacional por Amostragem Domiciliar); são hoje mais de dez milhões de chefes de família, em geral mulheres, - mães mas muitas vezes também avós que, para os nossos senadores, se tornaram mulheres sem rosto, chefiando familias invisíveis. Essas famílias, aliás, apesar do silêncio geral sobre elas, são mais numerosas que as de união estável $(26,1 \%$ contra $17,3 \%)$. A formulação de um novo Código Civil seria uma boa ocasião para estender ainda mais a previsão constitucional da família monoparental, incluindo, além dos "descendentes", também os enteados e os "filhos de criação" porque é isto o que muitas vezes acontece nessas famílias. A utilidade disso seria estender a um bom número de pessoas, todas as vantagens dadas pelas leis de proteção à família.

Quanto à união estável, o Projeto volta a tempos passados; a Lei $\mathrm{n}$. 9.278/96, que regulamentou o $\S 3^{\circ}$, do art. 226 da Constituição, nenhuma distinção criou entre casos diversos de convivência, mas o Projeto diferencia entre os conviventes que têm e os que não-têm impedimento para se casar; além disso, torna a fixar prazos para obtenção dos efeitos jurídicos (exige, em princípio, o prazo de cinco anos e, se houver filhos comuns, o de três anos). Até parece que com menos de cinco anos, os conviventes não se devem reciprocamente, lealdade, respeito e, assistência, ou - antes dos três anos não têm o dever de guarda, sustento e educação dos filhos (são os deveres previstos para os conviventes, em união estável, no art. 1.736 do Projeto)! Diante do espírito reacionário e discriminador, aqueles que amam a igualdade, talvez pudessem adaptar um velho lema: "o preço da igualdade é a eterna vigilância". Tanto isso é verdade que o Projeto (art. 1.739) volta a qualificar, em certos casos, a união de um homem e de uma mulher como "concubinato" palavra abolida pela Constituição e que possui conotação pejorativa.

Tratando dos efeitos do casamento, o Projeto, seguindo o que já é lei no mundo infeiro, fez a previsão da possibilidade, por acordo entre os cônjuges, de mudanças no regime de bens. Todavia, na crítica do professor J. B. Villela, ao invés de se contentar com a escrita pública e o registro, que bastariam para acautelar os direitos de terceiros, impõe decisão judicial. Este é, aliás, outro ponto nada atual do Projeto: a freqüente exigência da presença do juiz. Para converter a união estável em casamento, que a lei vigente admite que se faça por meio de requerimento ao oficial do cartório (art. $8^{\circ}$, da Lei n. 9.278/96), o Projeto exige que o pedido seja apresentado ao juiz (art. 1.738). Se pai e mãe discutem sobre o colégio em que deve ser matriculado o filho, a arbitragem, juridicamente, não pode ser feita por um padre, 
um rabino ou uma pessoa da família que seja de confiança de ambos, como seria natural, e sim, necessariamente, pelo juiz (cf. arts. 851 e $\S$ único do art. 1.643 do Projeto. Essa solução também é do direito vigente, mas já se sabe que não tem efetividade).

Sobre a separação judicial, o Projeto (art. 1.548), denotando um trabalho apressado de adaptação, manteve, ao lado do rol de causas típicas (solução própria do Código Civil de 1917), as previsões gerais da Lei do Divórcio (de 1977), que havia revogado o sistema anterior. O pior, porém, é que, para a separação judicial por separação de fato, que a lei atual exige o prazo de um ano $\left(\S 1^{\circ}\right.$. do art. $5^{\circ}$ da Lei do Divórcio), os senadores exigiram dois anos ( $\S 1^{\circ}$ do art. 1.576)! Será que a Câmara vai aceitar a revogação de toda a legislação que aprovou anteriormente?

Entre os pressupostos para conversão da separação de fato em divórcio (divórcio direto), o Projeto (art. 1.586) exige, repetindo a Lei n. 6.515 de 1977 (art. 40, IV), haver partilha dos bens do casal. Ora, os tribunais, inclusive com edição de súmula (Súmula n. 197 do S.T.J.), já decidiram que essa restrição se tornou inconstitucional e não mais vigora. O Projeto, como se vê, é decididamente "pré-Constituição de 88 " e já surge inconstitucional.

Quanto à união homossexual, de que o Projeto não trata, é verdade que essa união nem é família nem assim está na Constituição. Por outro lado, nesses casos, a questão patrimonial entre companheiros, tem solução no Direito das Obrigações, bastando utilizar o princípio fundamental que veda o enriquecimento sem causa, sendo que o Superior Tribunal de Justiça assim taınbém decidiu com base na idéia de sociedade de fato. Além disso, cumpre ainda dizer que o projeto de lei que foi apresentado no Congresso pela deputada Marta Suplicy não é realista e procura usar o direito privado para atender reivindicações de nível simbólico função para o qual o Direito Civil não se presta, diferentemente talvez do Direito Constitucional. Todavia, apesar de tudo isso, há problemas que permanecem; não parece justo, que, em caso de acidente e internação de uma pessoa que vive com outra (independentemente de manterem oul-não relações sexuais), quem vá decidir sobre operações cirúrgicas urgentes seja um parente que com ele pouco contato mantém. E se advém morte, por que é que somente um parente é que poderá autorizar doação de órgãos para transplante, ou defender o nome do falecido, ou resolver sobre situações como inumação ou cremação do corpo? Ora, considerando que, no livro "Do Direito de Família" do Código Civil, há um título que não trata da 
família, e sim, do que Clóvis Bevilacqua chamava de institutos complementares (tutela, curatela, ausência), o Projeto nele poderia prever, num capítulo sobre relações pessoais, algumas disposições dando atendimento às pessoas que morem juntas.

Passando rapidamente às relações de filiação, observo que os senadores introduziram em único artigo a expressão "inseminação artificial"; isto fizeram no lugar errado (art. 1.602), de forma atrasada porque, em termos de hoje, a inseminação artificial é somente uma das formas de reprodução assistida , e sem esclarecer se se trata de inseminação homóloga (isto é, com sêmen do próprio marido da mulher casada) ou heteróloga (isto é, com sêmen de outro). Este último ponto é fundamental porque, como se sabe, a Igreja veta a inseminação heteróloga; os católicos não tiveram oportunidade de tomar ciência dessa questão, porque os ilustres senadores não a discutiram com a sociedade civil (votaram o Projeto por voto de liderança!).

Por sua vez, a proibição de reconhecimento do filho adulterino $a$ matre, determinada no Projeto, contraria o $\S 6^{\circ}$ do art. 227 da Constituição, que não admite discriminação entre os filhos; para o Projeto (art. 1.626 e $\S$ único), esses filhos, ao contrário dos outros, somente poderão ser reconhecidos após a dissolução da sociedade conjugal ou após um ano de separação de fato.

Dizia Bergson que o progresso moral se verifica quando um povo, depois de viver sob determinada orientação, não quer mais voltar à anterior. $\mathrm{O}$ Projeto retrocede aos tempos anteriores à Constituição; será que as mudanças no Direito de Família feitas em 1988 não foram bem-aceitas pelo povo brasileiro ou será que são os senadores que estão alienados da nossa realidade?

São Paulo, julho de 1998. 